\title{
PW01-013 - Localization of alternative pyrin isoforms
}

\author{
E Tahir Turanli ${ }^{1,2^{*}}$, S Erdemir ${ }^{2}$, G Celikyapi Erdem ${ }^{2}$ \\ From 7th Congress of International Society of Systemic Auto-Inflammatory Diseases (ISSAID) \\ Lausanne, Switerland. 22-26 May 2013
}

\section{Introduction}

The importance of MEFV gene protein, Pyrin/Marenostrin $(\mathrm{P} / \mathrm{M})$ in the inflammatory pathway is well established. $\mathrm{P} / \mathrm{M}$ is expressed in neutrophils, eosinophils, monocytes, dendritic cells and synovial fibroblasts. There are many MEFV transcripts which are generated by alternative splicing events including deleted exons 2,3,4,5,7 and 8 in several combinations or individually. Some of these transcripts (2a, 2d, 8ext, 2d/8ext and 2d/9ext) were shown to be expressed as protein isoforms in leukocytes. A previous study carried out by our group has shown that exon 2 deleted form (d2) in leukocyte samples of FMF patients is expressed more than 400 fold compared to healthy control samples $(\mathrm{p}=0.026)$.

\section{Objectives}

Based on the hypothesis that different localizations and functions for full length and MEFV alternatively spliced transcripts, this study aimed to determine the localization differences between full-length $\mathrm{P} / \mathrm{M}$ and $\mathrm{P} / \mathrm{M}-\mathrm{d} 2$ protein isoforms in neutrophil-like cells in vitro.

\section{Methods}

Two GFP-tagged plasmids which are are pCMV6-AC-GFP + MEFV-fl (MEFV-fl-GFP) and pCMV6-AC-GFP + MEFV-d2 (MEFV-d2-GFP) were transfected to HL-60 (Human promyelocytic leukemia cells) cell lines and examined via confocal microscopy. Subsequently, six-day incubation with $1.75 \%$ DMSO was performed to differentiate HL-60 cells to neutrophil-like cells. These cells were also transfected with same plasmids and proteins were observed through confocal microscopy technique.

\section{Results}

Transfection studies showed that MEFV-fl-GFP was cytoplasmic and MEFV-d2-GFP was nuclear in HL-60 cell line. On the other hand, both MEFV-fl-GFP and MEFV-d2-GFP were localized in cytoplasm of neutrophil-like cells.

\section{Conclusion}

In previous studies, cellular localization of $\mathrm{P} / \mathrm{M}-\mathrm{fl}$ and $\mathrm{P} / \mathrm{M}-\mathrm{d} 2$ was investigated in several cell lines through using transfection methods or $\mathrm{P} / \mathrm{M}$ antibody. Transfection studies showed that full-length $\mathrm{P} / \mathrm{M}$ was generally cytoplasmic and $2 \Delta$ isoform was the only isoform which can enter nucleus but may also localize in cytoplasm. However localization studies using $\mathrm{P} / \mathrm{M}$ antibodies, which cannot currently distinguish between different isoforms, showed that although native $\mathrm{P} / \mathrm{M}$ consists of predominantly full-length type, protein was also observed in the nucleus of neutrophils. Our localization results of $\mathrm{P} / \mathrm{M}-\mathrm{fl}$ and $\mathrm{P} / \mathrm{M}-\mathrm{d} 2$ in HL-60 cells were compatible with literature, they were observed in the cytoplasm and nucleus, respectively. On the other hand, both $\mathrm{P} / \mathrm{M}-\mathrm{d} 2$ and $\mathrm{P} / \mathrm{M}-\mathrm{fl}$ isoforms were found to be localized only in cytoplasm not in nucleus in the neutrophil-like cells. These findings had led us to suggest that posttranscriptional modifications for P/M-d2 that may occur during cell differentiation or possibly through inflammation such that its natural localization in the nucleus may point to its role in the inflammation maybe like a transcription factor.

\section{Disclosure of interest}

None declared.

'Department of Molecular Biology and Genetics, Istanbul Technical

University, Turkey

Full list of author information is available at the end of the article

(c) 2013 Turanli et al; licensee BioMed Central Ltd. This is an Open Access article distributed under the terms of the Creative Commons Attribution License (http://creativecommons.org/licenses/by/2.0), which permits unrestricted use, distribution, and reproduction in any medium, provided the original work is properly cited. 


\section{Authors' details}

'Department of Molecular Biology and Genetics, Istanbul Technical

University, Turkey. ${ }^{2}$ Molecular Biology-Biotechnology and Genetics Research

Center, Istanbul Technical University, Istanbul, Turkey.

Published: 8 November 2013

doi:10.1186/1546-0096-11-S1-A66

Cite this article as: Turanli et al:: PW01-013 - Localization of alternative pyrin isoforms. Pediatric Rheumatology 2013 11(Suppl 1):A66.

Submit your next manuscript to BioMed Central and take full advantage of:

- Convenient online submission

- Thorough peer review

- No space constraints or color figure charges

- Immediate publication on acceptance

- Inclusion in PubMed, CAS, Scopus and Google Scholar

- Research which is freely available for redistribution 